\title{
Research on the Professional Development of ESP Teachers in Medical Colleges and Universities
}

\author{
Yuan Kong \\ Jining Medical University \\ Jining, China
}

\author{
Ya Kong* \\ Qufu Normal University \\ Qufu, China
}

\begin{abstract}
The purpose of this study is to investigate ESP teachers' knowledge and concepts, professional skills and training in Jining Medical University, so as to understand the current situation and problems of ESP teachers' professional development. With semi-structured interviews, ESP teachers and research managers were interviewed to further understand the problems and causes of ESP teachers' professional development. In view of the existing problems, this paper puts forward corresponding suggestions from both teachers' personal and school aspects. It is hoped that under the joint action of teachers and schools, ESP teachers' professional development will be promoted, so as to provide some reference for the professional development of ESP teachers and the construction of teaching staff in medical colleges and universities.
\end{abstract}

Keywords-medical colleges; ESP; teachers' professional development; current situation; strategies

\section{INTRODUCTION}

Along with the wide rise of ESP teaching in Colleges and universities, many scholars and experts have studied ESP from its connotation, teaching materials, teaching mode and curriculum setting. In recent years, researchers have paid special attention to ESP teachers. At the 5th ESP International Symposium, ESP teachers became the focus of discussion. The number and quality of ESP teachers were discussed in several papers submitted at the conference. In recent years, some academics have also discussed the quality of ESP teachers and the establishment of teaching staff in their articles. Many scholars and experts have also pointed out the problems of ESP teachers, and stressed that if the problems of ESP teachers can't be solved well, it will seriously affect the development of ESP teaching in China. However, there is still no consensus in academic circles on what qualified ESP teachers are, what professional knowledge and abilities they should possess and how to deal with the shortage of ESP teachers. With the wide rise of ESP teaching in colleges and universities, problems that the quality of ESP teachers can't meet the needs of ESP teaching are gradually exposed, and seriously restrict the development of ESP teaching in China. There is an urgent need to promote the professional development and quality of ESP teachers. Therefore, taking Jining Medical University as an example, this paper discusses the current situation and existing problems of ESP teachers' professional development from

This paper is sponsored by Scientific Research Support Fund for Teachers of Jining Medical University (Grant No. JYFC2018RW020); the Industry-University Cooperative Project of Ministry of Education (Grant No. 201801200014); The Visiting Scholar Funded Program of Young Backbone Teachers in Jining Medical University

Corresponding author: Ya Kong, Email: kongy_1116@163.com various different aspects and angles, and puts forward suggestions for the existing problems.

\section{ANALysis OF THE PROFESSIONAL DEVELOPMENT OF ESP TEACHERS}

The survey results show that nearly $75 \%$ of ESP teachers graduate from non-English majors and 65\% of ESP teachers do not have systematic knowledge of English language. It can be seen that more than half of ESP teachers have not received systematic language and linguistic knowledge, and their knowledge of language and linguistics is insufficient. Nearly $90 \%$ of teachers know about western culture, and more than $50 \%$ of teachers subscribe to books and magazines related to Western culture. It can be seen that ESP teachers pay close attention to and understand western culture. Therefore, ESP teachers can incorporate western culture into classroom teaching.

According to the theory of Dudley-Evens \& St. John, ESP teaching should follow the principles of authenticity, demand analysis and student-centered, which shows that students are the center of ESP teaching. However, according to the survey, only $36 \%$ of ESP teachers regard students as education centers. Dardley-Evans says ESP, as its name implies, is defined as an English course, not a special one. Its purpose is to improve learners' language awareness and language use skills in the professional field. As mentioned above, ESP teaching aims to improve students' language knowledge and skills. However, the survey found that only less than $50 \%$ of ESP teachers know the purpose of ESP classroom teaching. And less than 20\% of them regularly read ESP teaching and research magazines and periodicals in China. Therefore, ESP teachers do not pay attention to ESP related research and are not familiar with ESP related theories. If we know nothing about ESP teaching principles and purposes, it will be difficult to achieve ESP teaching in a real sense [1].

As a collaborator, ESP teachers should first cooperate with industry experts. Secondly, they should actively cooperate with students in teaching, which shows that the relationship between teachers and students in ESP classroom should be cooperative. However, only $10 \%$ of the respondents believed that ESP teachers and students were cooperative and communicative. ESP teachers, as evaluators, need to make a systematic evaluation of whether the designed curriculum and textbooks and the teaching methods used in the teaching process are scientific and reasonable. ESP teachers' role as evaluators can't be ignored. The survey found that more than $50 \%$ of ESP 
teachers do not know the criteria for evaluating classroom teaching, textbooks and self-evaluation. Less than 30\% of ESP teachers make long-term self-evaluation of teaching and research. Only $7.5 \%$ of ESP teachers pay attention to the demand for ESP talents in the talent market. This shows that ESP teachers are not aware of the importance of evaluation in ESP teaching, nor do they regard themselves as an evaluator in the process of teaching.

\section{PROBlems IN ESP TEACHERS' PROFESSIONAL DEVELOPMENT}

\section{A. Professional Knowledge Can't Meet the Requirements of ESP Teaching}

ESP teaching involves two aspects: professional knowledge and English knowledge. As ESP teachers, they need not only the professional knowledge, but also the language knowledge, which are the two basic indispensable elements. According to the survey results, ESP teachers in Jining Medical University come from professional teachers and general English teachers, of which professional teachers are the main ones, accounting for about $70 \%$ of the total number. College English teachers have a good foundation in English and the rich teaching experience. The ESP courses that they teach (such as Business English Audiovisual Course, Business English Translation Course, etc.) are related to English professional knowledge. They are all English majors and have studied Business English related courses. Their professional knowledge is competent for ESP teaching. In addition, nearly $70 \%$ of professional teachers are familiar with the stylistic characteristics of their major and have basic knowledge and practical experience of relevant professional courses. However, they lack language and linguistic knowledge, theories and methods of learning foreign languages, and ESP-related theories. Students have limited knowledge of English in the process of teaching because of the lack of linguistic knowledge of ESP teachers. In the long run, this will lead to the expansion of students' knowledge blind area, which is not conducive to students' comprehensive learning of theoretical knowledge. Understanding the theory and teaching knowledge acquired in the foreign languages may make the English-speaking ESP teachers not know what kind of teaching methods to use to promote the students' learning in the process of teaching, so that they can't achieve the desired results after spending a lot of effort. Unfamiliarity with ESP theory will be unfavorable for ESP teachers to grasp the teaching objectives and principles, and ultimately it can't achieve the true meaning of ESP teaching.

This is mainly due to the abnormal development of teachers in ESP system. At present, ESP teachers in Jining Medical University come from professional teachers and general English teachers, of which nearly $70 \%$ are professional teachers. At present, ESP teachers in Jining Medical University come from professional teachers and university basic English teachers, of which nearly $70 \%$ are professional teachers. Therefore, neither linguistic knowledge, foreign language acquisition theory and pedagogical knowledge nor ESP related theory can meet the requirements of ESP teaching and fundamentally guarantee the quality of ESP teaching. Of course, the emergence of this phenomenon is inseparable from the lack of ESP teachers in China.

\section{B. Professional Skills Do Not Meet the Needs of ESP Teaching}

ESP teachers, as implementers of teaching, must master certain basic ESP teaching skills and curriculum teaching skills, and possess certain ability of compiling textbooks, teaching and research and evaluation [2]. At the same time, we should also have the ability of demand analysis, be able to grasp the characteristics of the target language and analyze the needs of learners, so as to effectively provide learners with a shortcut to the target discourse community.

However, according to the analysis of the survey results, the professional skills of ESP teachers in Jining Medical University are relatively weak, mainly in the following aspects. Firstly, the ability of oral English expression is poor. There is a phenomenon that Chinese is used as the teaching language in ESP class. Few teachers teach in pure English. Education provided under the ESP programme aims to improve students' language skills. In ESP class, teachers use Chinese to teach, the English ability of students will not be exercised, which will inevitably make ESP teaching greatly discounted. Oral English expression ability has become one of the main obstacles to the professional development of English teachers. Secondly, the ability of compiling textbooks and teaching research is weak. ESP teachers are not only teachers, but also researchers. By practicing as a researcher, teachers can discover and study the characteristics of ESP teaching and construct an effective ESP teaching and learning model for students. However, a large number of ESP teachers have not written teaching research papers, never participated in teaching research projects, did not do teaching experiments, so their teaching research ability is poor. More than half of ESP teachers do not know how to compile textbooks, and their ability to compile textbooks is very weak. In the long run, the professional theory level of ESP teachers will not be refined and sublimated, and the external concept can't be gradually internalized, which will seriously restrict the development of ESP teaching and make ESP teaching stagnate. Thirdly, the ability of demand analysis needs to be strengthened. Needs analysis and research on the object and motivation of ESP teaching provide a theoretical basis for teaching decision makers and managers to guide and supervise the curriculum, point out the direction of teaching and project development for teachers, and set goals for students. This is also the distinction of ESP course. So ESP Teaching Teachers must have a certain ability of demand analysis. However, the survey results show that few ESP teachers do needs analysis in their daily teaching process, and even some teachers do not know how to do need analysis [3]. ESP teachers' needs analysis ability needs to be improved.

The emergence of these problems is inseparable from the fact that ESP teachers have not received systematic, comprehensive and targeted training and learning of professional skills. Therefore, ESP teachers' professional skills are similar to "Sky Garden". They lack solid foundation support and can't meet the needs of ESP teaching [4]. 


\section{Lack of Overall Arrangement for Professional Development}

\section{1) The criteria for selecting ESP teachers are too low}

The results show that Jining Medical University has no specialized higher education teachers. The general English teachers or professional teachers are appointed by the university as ESP teachers. Therefore, when appointing ESP teachers, the university only takes their interests, hobbies, educational level and English proficiency as the basis, and fails to take into account the professional quality of teachers and whether they are competent for ESP teaching. As a result, ESP teachers can't meet the requirements of ESP teaching due to the lack of professional knowledge, and the weak professional skills can't meet the needs of ESP teaching. This is mainly due to the low standard of selecting ESP teachers, which affects the overall quality of ESP teacher's group [5]. Although this selection method is conducive to the full and extensive use of existing teachers' resources in ESP teaching, it lowers the entry threshold of ESP teachers and makes the overall quality of ESP teachers not guaranteed. In the long run, it will inevitably have a serious impact on ESP teaching.

\section{2) The teaching task imposed is too heavy}

According to the results of the survey, ESP teachers in Jining Medical University are both professional teachers and basic college English teachers. That is, ESP teachers must not only complete their teaching tasks, but also attend specialized courses or general English courses. This undoubtedly increases the workload of ESP teachers, but ESP teachers' time and energy are very limited. The teaching of professional courses will inevitably consume ESP teachers' time and energy, so that they can't devote themselves wholeheartedly to ESP teaching work. Therefore, they can't devote themselves wholeheartedly to ESP teaching [6]. As a result, ESP teachers are unable to do what they want in professional development. In the long run, this will not only restrict the development of ESP education, but also have a negative impact on vocational education.

3) The training is lack of pertinence and systematicness

The survey results show that the training of ESP teachers in colleges and universities lacks pertinence. ESP teachers are mainly composed of professional teachers and general English teachers, so their needs for training are also different. Professional teachers need more English training and foreign language teaching methods, while ordinary English teachers need more training in related disciplines. However, most teachers say that the training of the university adopts a unified model, which is the same for both professional teachers and general English teachers. Such indiscriminate and non-targeted training not only wastes the time and energy of ESP teachers, but also fails to achieve the expected training objectives. The training of teachers in schools is not systematic. At present, ESP teachers are trained by three ways: in-school continuing education, inviting experts to guide them and sending them to exchange and learning. Among them, in-school continuing education and inviting experts to guide ESP teachers are two main ways. For the time of these two kinds of training, it is short and not fixed. After training, it is rare to receive continuous training [7]. For the content of the training, it is not systematic, such as inviting experts to lecture in school. Although all teachers can participate, but there is no cohesion between the contents of the experts' lectures and even the phenomenon of duplication of the content of the lectures will occur. Many teachers also reflected in the interviews that there were duplication of training content and little training gains.

\section{STRATEgIES FOR ESP TEACHERS' PROFESSIONAL DEVELOPMENT}

\section{A. ESP Teachers Should Enhance Self-Development Consciousness and Promote Self-Development}

As an ESP teacher, we should first have the needs and awareness of professional development, so that we can go further on the road of professional development. Only when teachers have the consciousness of self-development can they continuously create conditions for professional development, enrich their professional knowledge and improve their professional skills in teaching practice according to their own actual situation. Therefore, in the face of ESP teachers' insufficient professional knowledge and weak professional skills, ESP teachers should be a person of great interest in teaching and constantly strive for opportunities for selfdevelopment. By actively striving for opportunities to other departments to attend classes, they can make up for their own professional knowledge loopholes. In order to enrich practical teaching experience and improve teaching skills, it is necessary to discuss teaching problems with experts or colleagues quickly. Through active self-learning, they can become a qualified ESP teacher with rich English language knowledge and solid professional knowledge. At the same time, ESP teachers should not be passive receivers of professional development, but active constructors of their own professional development. In the process of education, they must actively study, find effective methods and strategies, and encourage students to learn. Through teaching practice, they can accumulate their own teaching experience in the process of teaching, try to push students to the front stage, transfer more learning and exercise opportunities to students to ensure students' central position in ESP classroom. They should not only not interfere with students' thinking, but also ensure that the content form and the results of their learning meet the requirements of ESP courses.

\section{B. ESP Teachers Should Insist on Teaching Reflection and Improve Professional Skills}

After teaching, the most easily ignored by ESP teachers is teaching reflection and self-evaluation. In fact, teaching reflection is the cornerstone of the professional development of teachers and should be included in all stages of education. Through reflecting on the various stages of the educational process, ESP teachers can timely adjust the teaching methods and contents and improve the teaching skills. Educational thinking is a widely used way in the field of education. Reflections in classroom teaching refer to teachers' investigation and systematic reflective research on the problems found in their teaching. The purpose is to constantly improve teaching methods, optimize teaching effects and improve teachers' teaching skills [8].

Therefore, ESP teachers who are weak in oral expression, textbook compilation, teaching research and needs analysis can follow the following steps to reflect on teaching in their 
teaching process. The first is collection and accumulation of research data through audio-visual recording, student test scores and teaching logs. Secondly, through the analysis of the collected and accumulated data, ESP teachers can find out and reflect on the problems in teaching, and find the corresponding solutions and strategies for the problems. Thirdly, after repeated testing and verification of the solutions and strategies in teaching, they can make further adjustment or improvement. Finally, they should continue to optimize and improve teaching methods and skills to promote career development.

\section{Colleges and Universities Enhance the Entry Threshold of ESP Teachers and Ensure the Overall Quality of Teachers}

The low selection criteria and entry threshold of ESP teachers directly affect the overall quality of ESP teachers, so that the professional knowledge and ability of them can't meet the requirements of teaching. There are no full-time ESP teachers in Jining Medical University. ESP teachers are appointed by the school as professional teachers and general English teachers. Although they save manpower costs to some extent, professional teachers and general English teachers are not full-time ESP teachers. On the one hand, ESP teaching must be completed. On the other hand, they also need to consider professional courses. Therefore, they do not have enough time and energy to teach and learn within the framework of the ESP, which constitutes a serious obstacle to the professional development of ESP teachers. Moreover, not every teacher can be competent for ESP teaching. ESP teaching has higher requirements for ESP teachers. Therefore, when selecting ESP teachers, the university should re-examine the entry threshold of ESP teachers, improve the entry criteria of them, and ensure that the selected ESP teachers have the professional knowledge and competence required for ESP teaching, so as to ensure the reliable quality of ESP teaching.

At the same time, when appointing ESP teachers, universities should not concentrate on in-service teachers, but should also take a long-term view. They can employ ESP teachers from outside schools or professional ESP teachers from abroad to serve as ESP teachers. This is an effective way to solve the shortage of ESP teachers quickly and effectively in the education sector. It is also a reliable way to ensure that universities have a sufficient number of qualified ESP teachers.

\section{Colleges and Universities Should Attach Importance to ESP Teachers' Professional Development and Take Effective Incentives}

It is an important way to arouse ESP teachers' enthusiasm and motivation to pay more attention to ESP teachers' professional development and take effective incentive measures.

According to the survey of ESP teachers' selection and training, Jining Medical University does not have a management and assessment system for ESP teachers, nor does it provide specific and unified training for ESP teachers. This has greatly hampered ESP teachers' enthusiasm for work and, to a certain extent, frustrated ESP teachers' enthusiasm for work. Therefore, the university should formulate appropriate assessment system to incorporate ESP courses into normal teaching management. The university examines the ESP teachers and students at the end of each semester. On the one hand, it examines students' learning achievements and understands students' knowledge. On the other hand, the university rewards excellent teachers and teachers who have made great progress in teaching according to the results of ESP teachers' assessment, and encourages other teachers to learn from excellent teachers, so that ESP teachers feel the concern and attention of the university on them, so as to improve the enthusiasm of ESP teachers. At the same time, by formulating clear teaching plan template, defining clear teaching objectives and contents, setting reasonable ESP class hours, strengthening the management of ESP teachers, standardizing ESP teaching classes, let ESP teachers, like other subject teachers, formulate clear teaching plans according to clear teaching objectives, so as to ensure the normal and orderly progress of ESP teaching.

Environment is an important factor affecting teachers' professional development. Therefore, in the process of promoting ESP teachers' professional development, colleges and universities should create a good professional development environment and guide ESP teachers to carry out selfprofessional development planning. The team building of teachers is not an overnight process, but a long-term process. As the main position of teachers' professional development, colleges and universities should actively create a favorable environment for teachers' professional development and provide various favorable conditions for ESP teachers' professional development to the greatest extent. School leaders should be concerned about ESP teachers' work and life, and reduce ESP teachers' teaching burden. Let ESP teachers have enough time to conduct ESP teaching research in a relaxed and pleasant working environment [9]. Build various platforms for ESP teachers' professional development. Let ESP teachers have more opportunities to learn and communicate with each other, broaden ESP teachers' horizons, stimulate ESP teachers' professional development potential, and create a stage for ESP teachers to show themselves. (3) Establish ESP school alliance to form a certain scale of ESP teaching in a certain region, thus creating a large environment for ESP teaching, so that ESP teachers can learn from each other's strengths and complement each other's weaknesses, and quickly realize professional development.

\section{E. Colleges and Universities Should Provide Targeted and Systematic Training to Ensure the Quality of Training}

ESP Teachers' training should meet their actual needs. They are mainly professional teachers and basic college English teachers, whose different professional knowledge structure determines the different content of ESP teacher training. In order to meet the development needs of ESP teachers to the greatest extent, colleges and universities should provide a systematic and targeted training for ESP teachers' professional development.

Understand the training needs and arrange the training contents pertinently. Through their own communication platform, questionnaires, interviews and discussions, the colleges and universities understand the needs of ESP teachers' professional development and define the objectives of ESP teachers' training. In view of the weakness of ESP teachers' 
oral expression ability, we should vigorously carry out language training. From the composition, sentence pattern and grammatical characteristics of professional English to reading and writing ability, teachers can clearly grasp the knowledge structure of professional English and improve the overall language ability. In view of ESP teachers' ignorance of ESP theory knowledge, special lectures on ESP theory were conducted. ESP experts are invited to systematically explain and impart ESP-related theoretical knowledge, so that teachers can have a clear understanding of the origin and development of ESP-related theoretical knowledge, better grasp the purpose and methods of ESP teaching, improve teaching skills, promote teachers' professional development, and make ESP teachers take less detours on the road of professional development [10].

According to the teacher's preference for training methods, choose the appropriate training methods or ways. Colleges and universities should investigates the training methods or ways ESP teachers like, and finds out which training method or way ESP teachers are willing to accept and which one they dislike. The training methods such as deliberation, observation and study abroad, which most teachers are keen on, should be taken into consideration as far as possible. To organize and carry out training around the way they are keen on, which not only greatly improves teachers' interest in training, but also fully mobilizes teachers' enthusiasm and initiative, and ultimately quickly realizes teachers' professional development, achieves the expected training effect, and achieves a win-win situation between the universities and teachers.

Arrange reasonably the training time and quantity to ensure the integrity and systematicness of training. The duration of training, whether long-term or not, and the frequency of training has a significant impact on the effectiveness of training. Therefore, colleges and universities should arrange the time and quantity of training scientifically and reasonably, so as to make the training more cohesive to ensure that teachers can receive continuous and complete training after training, so that the training content can be effectively and timely integrated to improve efficiency and quality.

\section{CONCLUSION}

ESP is an important part of College English teaching. The strengthened ESP education is an effective means to improve students' practical ability in theoretical connection. Teachers are indispensable to the development of teaching. The teacher training is the key to the success and failure of education. The professional development of the teachers is the core of the construction of the ranks of teachers. With the extensive development of ESP teaching in China, the problems of ESP teachers' team are increasingly exposed, and the professional development of ESP teachers has attracted more and more attention. In order to understand the current situation and problems of ESP teachers in vocational training, this study, taking Jining Medical University as an example, and combining relevant literature research, through questionnaire survey and interviews, from the aspects of teachers' knowledge and concept, teaching and research ability, training and refresher, professional attitude, etc., studies the professional development of ESP teachers. The study finds that ESP teachers have the following problems in their professional development: 1) ESP teachers lack English language knowledge, foreign language acquisition theory knowledge and pedagogical knowledge. They are not familiar with ESP theory and their skills do not meet the requirements of ESP teaching; 2) Oral English expression ability, textbook writing ability, teaching research ability and demand analysis ability are relatively weak, and professional ability does not meet the needs of ESP teaching; 3) The professional development of ESP teachers lacks the entire arrangement. To solve these problems, the researcher puts forward solutions and suggestions from both teachers themselves and colleges and universities, hoping to provide reference for the professional development of ESP teachers and training of teachers in colleges and universities.

\section{REFERENCES}

[1] P. Davies, E. Pearse, Success in English Teaching, Shanghai: Shanghai Foreign Language Education Press, 2002.

[2] Dudley-Evans, Tony. Developments in English for Specific Purposes: A Multi-Disciplinary Approach, Cambridge: Cambridge University Press, 1998.

[3] R. Fesssler, J. C.Christen, The Teacher Career Cycle: Understanding and Guiding the Professional Development of Teachers, Boston: Allyn and Bacon, 1992.

[4] L. Gavioli, Exploring Corpora for ESP Learning, Amsterdam: John Benjamins, 2005

[5] Teachers' Department, Ministry of Education, Theory and Practice of Teachers' Professional Development (Revised Edition), Beijing: People's Education Press, 2003.

[6] Department of Higher Education, Ministry of Education, Requirement for College English Teaching, Beijing: Higher Education Press, 2007.

[7] Ministry of Education, Some Opinions on Strengthening Undergraduate Teaching in Colleges and Universities and Improving Teaching Quality, Ministry of Education, Political Newspaper, 2001.

[8] L. P. Chen, A Study of ESP, Shanghai: Fudan University Press, 2000

[9] J. Tian, "Research on teachers' team construction of ESP teaching in higher vocational colleges,” Foreign Language World, No. 2, 2014.

[10] L. Yang, J. E. Yang, "Research on ESP teacher development strategy in transitional period,” Contemporary Education Science, No. 9, 2014 